BBA 86037

\title{
BIOGENESIS OF MITOCHONDRIAL ATPase
}

\section{WALTER SEBALD}

Institut für Physiologische Chemie und Physikalische Biochemie der Universität München, 8000 München 2, Goathestraße 33 (G.F.R.)

(Received July 21st, 1976)

\section{CONTENTS}

I. Introduction . . . . . . . . . . . . . . . . . . . . . . . 1

II. Experimental approaches . . . . . . . . . . . . . . . . . . . . . . . . . 2

III. Biogenesis of functionally defined components of ATPase complex . . . . . . . . . . 3

A. $F_{1}$, OSCP and $F_{1}$-inhibitor . . . . . . . . . . . . . . . . . . . . . . . . . 3

B. Membrane factor . . . . . . . . . . . . . . . . . . . . . . . . . . . . . 4

IV. Oligomycin-sensitive ATPase . . . . . . . . . . . . . . . . . . . . . . . . . . 6

A. Isolation and subunit composition . . . . . . . . . . . . . . . . . . 6

B. Identification of mitochondrially synthesized subunits . . . . . . . . . . . . . 10

C. Assembly . . . . . . . . . . . . . . . . . . . . . . . . . 15

D. Isolated hydrophobic subunits . . . . . . . . . . . . . . . . . . . . . . 18

V. ATPase mutants . . . . . . . . . . . . . . . . . . . . . . . . . . . 22

A. Cytoplasmic mutants . . . . . . . . . . . . . . . . . . . . . . . . . . . 22

B. Nuclear mutants . . . . . . . . . . . . . . . . . . . . . . . . . 23

VI. Concluding remarks

Acknowledgement . . . . . . . . . . . . . . . . . . . . . . . . . . . . . 24

References ........................... 25

\section{INTRODUCTION}

Studies on mitochondrial ATPase in the field of oxidative phosphorylation and studies on the biogenesis and genetics of mitochondria have converged in the last few years. It is now well established that mitochondrial DNA and mitochondrial protein synthesis play an essential role in the formation of the ATPase complex as well as of cytochrome oxidase and cytochrome $b c_{1}$ (for recent reviews, see refs. 1-7). Of the numerous polypeptides which are present in these enzymes some are synthesized on mitochondrial ribosomes and some on cytoplasmic ribosomes. Mitochondrial and nuclear genes specify their synthesis.

Remarkable progress has been made in defining the contribution of the two

Abbreviations: $F_{1}$, soluble oligomycin-insensiłive ATPase; OSCP, oligomycin-sensitivity conferring protein; DCCD, dicyclohexylcarbodiimide 
cellular systems to the biogenesis of mitochondrial ATPase. We are, however, far from understanding other important aspects of the biogenetic process. No data are available on the composition and sequence of intermediates occurring during the assembly of the enzyme protein. The intriguing problem of how the polypeptides of the ATPase complex are transported through and into the mitochondrial inner membrane remains unsolved. No real attention has been paid to the lipid constituents which may also be important for the assembly of ATPase. Thus, the present review is restricted mainly to the description and discussion of experiments which clarify the role of mitochondrial and cytoplasmic protein synthesis as well as the role of mitochondrial and nuclear genes in the biogenesis of the ATPase complex.

I have relied in many points on the reviews of Tzagoloff [1]: "Biosynthesis of Mitochondrial Membrane Proteins", of Senior [8]: "Structure of Mitochondrial ATPase" and of Kovać [5]: "Biochemical Mutants: An Approach to Mitochondrial Energy Coupling”, which all appeared in BBA reviews on bioenergetics.

\section{EXPERIMENTAL APPROACHES}

Inititally, biogenesis of mitochondrial ATPase was studied almost exclusively in the yeast Saccharomyces cerevisiae. More recently the site of synthesis of the individual ATPase subunits has been investigated in Neurospora crassa. Both microorganisms represent eukaryotic cells with high biosynthetic activities and are readily cultured. The growth of $N$. crassa depends on the presence of oxygen. $S$. cerevisiae can switch from fermentative to aerobic metabolism with a concomitant induction of mitochondrial ATPase [9-13] and respiratory enzymes.

Two approaches were used in investigating the synthesis of ATPase proteins:

(1) In one type of experiment the formation of the functionally defined components of the ATPase complex $\left(\mathrm{F}_{1}, \mathrm{OSCP}, \mathrm{F}_{1}\right.$-inhibitor and membrane factor) was studied. The synthesis of these ATPase subfractions was measured by means of their functional activities (see section III).

(2) The synthesis of individual ATPase subunit polypeptides was investigated by the incorporation in vivo of radioactive amino acids. These experiments were performed mainly with preparations of oligomycin-sensitive ATPase whose polypeptides were separated by dodecyl sulfate gel electrophoresis (see section IV). Whereas in the tracer studies even small amounts of newly synthesized protein were detected, the synthesis of the functionally defined components could by only determined in long-term experiments.

In order to identify the translational origin of a protein, either the mitochondrial or the cytoplasmic protein synthesis has to be eliminated or inhibited. Inhibitor studies are based on the well known fact that cytoplasmic ribosomes can be specifically blocked by cycloheximide [14-17], whereas other antibiotics like chloramphenicol interrupt specifically the mitochondrial ribosomes [18-20]. The effect of the mitochondrial inhibitors is mimicked in the cytoplasmic petite mutants of 
yeast [5] which are unable to perform mitochondrial protein synthesis. The advantages and disadvantages of these approaches have been discussed by Schatz and Mason [2].

The genes involved in the biogenesis of mitochondrial ATPase have been studied in two types of mutants of yeast. One group of mutants was selected by growth resistance to specific inhibitors of mitochondrial ATPase (oligomycin, venturicidin, triethyltin, aurovertin). Another group of mutants was selected by their inability to grow on nonfermentable carbon sources. In a few of the latter mutants specific lesions in the ATPase complex were established (see section V).

\section{BIOGENESIS OF FUNCTIONALLY DEFINED COMPONENTS OF ATPase COMPLEX}

\section{IIIA. $F_{1}, O S C P$ and $F_{1}$-inhibitor}

Mitochondrial ATPase can be resolved into three functionally defined components: $F_{1}$, OSCP and membrane factor. Additionally a natural $F_{1}$-inhibitor has been isolated and characterized. These constituents were first established in the beef heart enzyme [21-26] and later in the enzyme from yeast [10-12, 27-29]. $F_{1}$, OSCP and $\mathrm{F}_{1}$-inhibitor are water-soluble proteins and have been obtained in pure or enriched form. The membrane factor could not be sufficiently purified up to now and has been studied either at the level of the membrane or in preparations of oligomycin-sensitive ATPase.

$F_{1}$. The biogenesis of $F_{1}$ was first investigated in yeast mutants which are unable to perform mitochondrial protein synthesis (see section V). These cytoplasmic petite mutants contain ATPase activity which is associated with the mitochondrial fraction [30-32]. Schatz isolated a $F_{1}$ ATPase which appeared to be unchanged compared to the wild type with respect to enzymic properties, sedimentation coefficient and immunological specificity [31]. Thus demonstrating that the $F_{1}$ component of the ATPase complex is synthesized on cytoplasmic ribosomes.

Tzagoloff used yeast cells undergoing glucose derepression for biogenetic studies [10 -12]. Cells grown at high concentrations of glucose (5.4\%) exhibit low activity of mitochondrial ATPase. A transfer of the cells to a low-glucose medium $(0.8 \%)$ leads within 6-7 h to a 2-3-fold increase in ATPase activity. This increase has been found to be accompanied by an increase in the $F_{1}$ content of the membrane [10]. The synthesis of $F_{1}$ protein is completely prevented by cycloheximide. In the presence of chloramphenicol, however, normal levels of $F_{1}$ activity are elaborated [10]: chloramphenicol-resistant synthesis of all subunits of $F_{1}$ has been demonstrated [33]. These findings confirm and extend the results obtained with the cytoplasmic petite muta!nts

Discrepancies exist, however, with regard to the intracellular localization of the $F_{1}$ synthesized in the absence of mitochondrial protein synthesis. In derepressing chloramphenicol-treated yeast, $F_{1}$ was recovered in the postribosomal supernatant $[10,12]$, whereas in the mutant it was found to be associated with the mitochondria [30-32). This point will be discussed in section IVC. 
$O S C P$. In yeast the presence of an oligomycin-sensitivity conferring protein (OSCP) has been established [11]. As in beef heart, this protein is necessary for the binding of $F_{1}$ to mitochondrial membrane and thus is one of the components which are essential for cold-stable and oligomycin-sensitive ATPase. The activity of OSCP increases during glucose derepression two to three fold as shown by reconstitution experiments with OSCP-enriched fractions [11]. The elaboration of this activity depends on the function of cytoplasmic protein synthesis. An inhibition of mitochondrial protein synthesis by chloramphenicol leads to normal activities which have been recovered in the postribosomal supernatant after cell breakage [11]. These results strongly suggest that OSCP, like $F_{1}$ is provided by the extramitochondrial system.

Remarkably, OSCP from yeast has not been found to form a complex with $F_{1}$. It is bound, however, to OSCP-depleted membranes in the presence and absence of $F_{1}[11]$. This differs from beef heart where a tightly bound complex of OSCP and $\mathrm{F}_{1}$ has been observed [34, 35].

$F_{1}$-inhibitor. A small polypeptide of about 10000 daltons has been isolated from beef heart mitochondria which inhibits mitochondrial ATPase by binding to $F_{1}$ [26]. The inhibitor may have an important regulatory function since it inhibits ATPase but not ATP synthetase activity [26,36-38]. Initially, the polypeptide could not be detected in yeast [39]. This may be attributed to the action of intracellular proteases, since the inhibitor protein is known to be highly sensitive to proteolytic digestion. Ebner reported the isolation of an ATPase inhibitor from yeast [28]. The inhibitor could not be detected in a cytoplasmic petite mutant by the ATPase-inhibition assay or by quantitative immunoprecipitation. Its presence, however, could be demonstrated in a nuclear mutant (pet 936; see section VB) which is deficient in $F_{1}$. These findings suggest that the synthesis of $F_{1}$ and of the inhibitor are regulated differently.

In Candida utilis the level of inhibitor was found to change with the metabolic status [29]. The inhibitor activity was two to four times lower in cells grown on $5 \%$ glucose than in cells grown in the presence of $3 \%$ glycerol.

No data are currently available on the site of synthesis of the inhibitor polypeptide.

\section{IIIB. Membrane factor}

It was already recognized during the early studies on the ATPase complex in the cytoplasmic petite mutants of yeast that the mitochondrial ATPase is altered $[30,31]$. In contrast to the wild type, ATPase activity in the mutant mitochondria is resistant to oligomycin and instable in the cold. Since $F_{1}$ was found to be unaltered (see above) it was assumed that the modification of the whole complex was caused by an impaired binding of $F_{1}$ to the mitochondrial inner membrane [31]. It was also suggested that a protein constituent of the membrane factor, or the membrane factor itself, is missing in the mutant mitochondria.

Positive evidence for the involvement of mitochondrially synthesized polypep- 


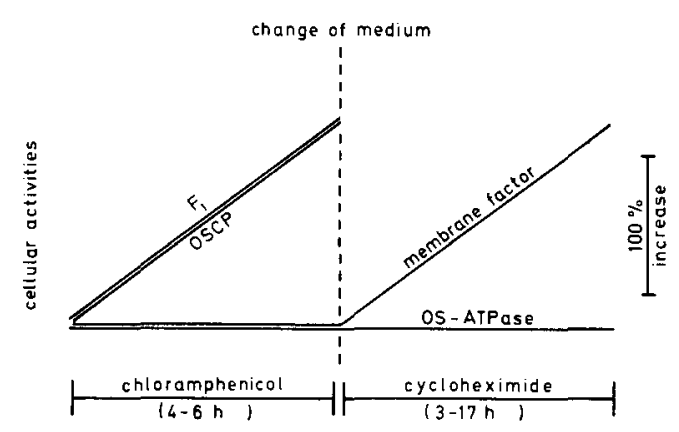

Scheme 1. Effect of sequential exposure to chloramphenicol and cycloheximide on the increase of $\mathrm{F}_{1}$, OSCP, membrane factor and oligomycin-sensitive ATPase in yeast. Yeast cells were grown in $5.4 \%$ glucose medium to early stationary phase. They were then transferred to a $0.8 \%$ glucose medium containing chloramphenicol $(2 \mathrm{mg}$ per $\mathrm{ml}$ ) and aerated for $4-6 \mathrm{~h}$. Thereafter the cells were washed with water, inoculated into $0.8 \%$ glucose medium containing cycloheximide $\left(10^{-5} \mathrm{M}\right)$ and further aerated for 3-17 h. $\mathrm{F}_{1}$ and OSCP were determined in the post-ribosomal supernatant. Membrane factor activity was measured in mitochondrial membranes extracted with $\mathrm{NaBr}$ and $\mathrm{NH}_{4} \mathrm{OH}$. After Tzagoloff [12].

tides in the formation of the membrane factor was obtained by experiments with derepressing yeast [12]. As in beef heart, the activity of the membrane factor could be measured in mitochondrial membranes which had been depleted of $F_{1}$ and OSCP by extraction with $\mathrm{NaBr}$ and ammonium hydroxide [12]. Addition of $\mathrm{F}_{1}$ and OSCP to depleted membranes restored oligomycin-sensitive and cold-stable ATPase activity. During glucose derepression a two to three fold increase of the membrane factor was determined by means of the in vitro reconstitution assay [12].

Both cycloheximide and chloramphenicol prevented an increase in membrane factor activity. This suggested that the synthesis of this component is in some way dependent on the function of both the mitochondrial and the cytoplasmic protein synthesizing systems [12].

A sequential exposure of the cells under derepressing conditions first to chloramphenicol for 4-6 $\mathrm{h}$ and then to cycloheximide for 3-17 h led to the full elaboration of membrane factor activity (Scheme 1). This result has been interpreted to indicate that the membrane factor is synthesized on mitochondrial ribosomes and that its synthesis is stimulated by products of the cytoplasmic system (see also section IVC). Despite the fact that the reconstitution experiment showed an increase of membrane factor, the specific activity of mitochondrial oligomycinsensitive ATPase remained under these conditions as low as in repressed cells (Scheme 1). Apparently, the membrane factor synthesized in the presence of cycloheximide is not assembled in vivo with the $\mathrm{F}_{1}$ and the OSCP accumulated during the chloramphenicol incubation.

Summary. The studies on the functionally defined components of the ATPase complex clearly showed the cytoplasmic synthesis of $F_{1}$ and OSCP, whereas the 
translational origin of the membrane factor could not be finally established. The membrane factor is not detected by functional criteria in the cytoplasmic petite mutants. On the other hand, chloramphenicol as well as cycloheximide prevent its appearance in derepressing yeast indicating an interdependency of both protein synthesizing systems in the formation of this component.

In order to clarify these interdependencies labelling experiments were done to see whether any polypeptide subunits of the membrane factor are synthesized on mitochondrial ribosomes. Since the membrane factor itself could not be isolated, these tracer studies were performed with preparations of oligomycin-sensitive ATPase, which contained in addition to the subunits of $F_{1}$ and OSCP at least those polypeptides of the membrane factor which are responsible for the oligomycin sensitivity and cold stability of the enzyme.

\section{OLIGOMYCIN-SENSTIVE ATPase}

\section{IVA. Isolation and subunit composition}

Functional oligomycin-sensitive ATPase can be solubilized in the presence of mild detergents like cholate, deoxycholate and Triton X-100. The procedures described for the isolation of the enzyme from beef heart and yeast have been reviewed by Senior in 1973 [8]. Since then the enzyme has been also obtained from $N$. crassa [40] and Schizosaccharomyces pombe [41]. For biogenetic studies the enzyme protein can be isolated by immunoprecipitation. This elegant method was introduced by Tzagoloff and Meagher [42]. Triton X-100 extracts of submitochondrial particles [42] or even of whole mitochondria [43] were incubated with antisera prepared against $F_{1}$ or whole oligomycin-sensitive ATPase. Analysis of the immunoprecipitates revealed the presence of the same polypeptides as in the functional enzyme.

Subunit compositions of oligomycin-sensitive ATPase as revealed by dodecyl sulfate gel electrophoresis [44, 45] have been described for the enzymes from yeast $[42,46]$, beef heart [47-50], N. crassa [40, 43] and Schizosaccharomyces pombe [41]. In some of these preparations the apparent molecular weights of the polypeptides have been calculated and the subunits of $F_{1}$ have been identified. These preparations are shown in Table I. The molecular weights in brackets indicate polypeptides which were considered not to be essential for oligomycin-sensitive ATPase activity.

Tzagoloff and Meagher identified 10 different polypeptides in oligomycin-sensitive ATPase from yeast $[1,42,51]$. The polypeptide with a molecular weight of 7500 was only detected by separation of radioactive proteins, since it stains poorly. The 12000 -dalton band was found to contain two polypeptides. The subunit composition of $F_{1}$ is unusual. One of the two small subunits did not appear and an additional polypeptide of 38500 daltons was observed. OSCP was tentatively correlated with the 18500 -dalton band, in analogy to the beef heart protein [52]. The four other polypeptide bands were attributed to the membrane factor. Capaldi observed in the 


\section{TABLE I}

APPARENT MOLECULAR WEIGHTS OF POLYPEPTIDES OF OLIGOMYCIN-SENSITIVE ATPase

All molecular weights have been determined by dodecyl sulfate gel electrophoresis $[44,45]$. Asterisked molecular weights indicate polypeptides which were correlated with subunits of $F_{1}$. The molecular weights in brackets represent polypeptides which were considered not to be essential for oligomycinsensitive ATPase acitivity. The square-bracketed numbers are Reference list numbers. The enzyme protein from rat heart was obtained by immunoprecipitation with antisera to rat heart $F_{1}$ (GrafKoller, G. and Sebald, W. unpublished data).

\begin{tabular}{lcccc}
\hline $\begin{array}{l}\text { Saccharomyces } \\
\text { cerevisiae [42] }\end{array}$ & Beef heart [47] & $\begin{array}{l}\text { Neurospora } \\
\text { crassa }[40,43]\end{array}$ & $\begin{array}{l}\text { Schizosaccharomyces } \\
\text { pombe }[41]\end{array}$ & Rat heart \\
& $(73000)$ & $(65000)$ & & $(70000)$ \\
$58500^{*}$ & 55000 & $59000^{*}$ & $61000^{*}$ & $59000^{*}$ \\
$54000^{*}$ & $55000^{*}$ & $56000^{*}$ & $58000^{*}$ & $56000^{*}$ \\
& $52000^{*}$ & $(45000)$ & 51000 & \\
$38500^{*}$ & $(45000)$ & $(38000)$ & 36000 & 36000 \\
$31000^{*}$ & & $36000^{*}$ & $32000^{*}$ & $32000^{*}$ \\
29000 & $30000^{*}$ & 22000 & & \\
22000 & 29000 & 21000 & 19000 & 22000 \\
18500 & 20000 & 19000 & 17000 & 21000 \\
& 19000 & 16000 & & 15000 \\
$12000^{*}$ & & $15000^{*}$ & $14000^{*}$ & $14000^{*}$ \\
12000 & $12500^{*}$ & $12000^{*}$ & 9000 & $8000^{*}$ \\
7500 & 10000 & 8000 & $8000^{*}$ & - \\
\hline
\end{tabular}

beef heart enzyme 10 polypeptide bands [47]. One of them with a molecular weight of 73000 was considered to be a contaminant. A further band of 45000 was present only in an enzyme prepared according to the method of Kagawa and Racker [53]. OSCP isolated in homogeneous form [52] exhibited the same electrophoretic mobility as the 19000 -dalton polypeptide. Extraction of the isolated enzyme protein with $\mathrm{NaBr}$ solubilized the five subunits of $\mathrm{F}_{1}$. The residue contained, in addition to OSCP, polypeptides with molecular weights of 55000,29000, 20000 and 10000 . The 55 000-dalton band was believed to be different from the largest subunit of $F_{1}$.

The oligomycin-sensitive ATPase from $N$. crassa exhibited, after gel-electrophoretic separation and staining with Coomassie Blue, 11 polypeptide bands (Fig. 1). In immunoprecipitated ATPase the same 11 bands were present, but in addition bands of 65000,50000 and 38000 daltons were observed (Fig. 2). All polypeptides were also recognized by the distribution of a homogeneous $\left[{ }^{14} \mathrm{C}\right]-$ leucine label which had been incorporated in vivo. The resolution of labelled polypeptide bands is worse than in the stained gels due to the slicing technique used for determination of the radioactivity. Remarkably, two bands (19000 and 11000 daltons) which are hardly seen on the stained gels are quite prominent in the radio- 
activity pattern. The five subunits of $F_{1}$ correspond to the polypeptides of 59000 , $56000,36000,15000$ and 12000 daltons (Figs. 1 and 2). A DCCD-binding protein migrated with the smallest polypeptide band of 8000 daltons (see also section IVD). The DCCD-binding protein from beef heart exhibited an apparent molecular weight which was higher than that of the two small subunits of $F_{1}$ [54].

The polypeptide pattern of the enzyme from Schizosaccharomyces pombe as described by Goffeau et al. [41] was very similar to that from beef heart. The intensities of some bands, however, were found to be rather low. This may be correlated with the observation that the ATPase is inhibited to only $30-50 \%$ by oligomycin.

Whereas in former times mainly the similarities of the polypeptide patterns were emphasized (e.g. in ref. 8) sufficient data are now available to discuss the differences, especially with respect to the number and molecular weights of the polypeptides.

The same apparent molecular weights have been determined for the five subunits of $F_{1}$ from beef heart and rat liver [55]. We have compared the $F_{1}$ polypeptides from beef heart and rat heart as well as from Neurospora and yeast. In all organisms the two largest subunits exhibited the same electrophoretic mobility, whereas the molecular weights of the three smaller subunits were found to be higher in Neurospora. Thus, real differences exist in the size of some polypeptides between different organisms. It should be also noted that for special polypeptides no reliable molecular weights are determined by dodecyl sulfate gel electrophoresis. In Neurospora, the electrophoretic mobility of one polypeptide ("19000-dalton") exhibited an unusual response to gel concentration. A lower molecular weight was determined when the electrophoresis was performed at lower gel concentrations [43]. A similar effect has been observed with some hydrophobic subunit polypeptides of cytochrome oxidase [56-58].

At present it cannot be decided whether oligomycin-sensitive ATPase activity depends on the same set of polypeptides in different organisms. Some variations in the number of polypeptide bands observed between the different enzymes, however, may be explained by experimental details.

(1) Dodecyl sulfate gel electrophoresis may not resolve all individual polypeptides. For example, the small polypeptide of about 8000 daltons which is seen in the yeast and Neurospora enzyme may not be detected in the beef heart ATPase, since it may coincide with the smallest subunit of $F_{1}$.

(2) In yeast and Neurospora some bands were found to stain poorly. They could only be detected by special techniques.

(3) Variable polypeptide bands were observed. In beef heart the amounts of some polypeptides vary in different enzyme preparations [48-50]. In functional oligomycin-sensitive ATPase from Neurospora three bands are low or absent which are prominent in the immunoprecipitated enzyme protein. Isolation of the ATPase at low detergent concentrations resulted in the appearence of a further polypeptide of 30000 daltons (see section IVB; Fig 5). In Schizosaccharomyces even $F_{1}$ was 
found to contain varying amounts of a polypeptide of 38000 daltons [59].

Apparently, these variable proteins are not essential for the activity of oligomycin-sensitive ATPase. The energy-transducing ATPase in situ, however, may contain additional polypeptides, which are not firmly bound. The ATPase inhibitor $[8,60]$ and the ADP/ATP carrier [61,62], for example, may be such polypeptides.

On the other hand, artificial polypeptide bands may be formed during the isolation of the enzyme protein. Intracellular proteases have been shown to cause the break-down of several membrane proteins. Cytochrome $c_{1}$ from yeast [63] and the ADP/ATP carrier [62] were found to be degraded to smaller polypeptides under certain conditions. We were not able to isolate a five-subunit $F_{1}$ from Neurospora in the absence of the protease inhibitor phenylmethylsulfonylfluoride. It has been discussed that some chloroform/methanol-soluble proteins of low molecular weight originate from the proteolytic break-down of larger hydrophobic proteins [64].

Considering these problems, it is not amazing that the stoicheiometry of the subunit polypeptides of oligomycin-sensitive ATPase could not be established up to now. Even the molar ratios of the five polypeptides present in $F_{1}$ are still under discussion $[65,66]$.

\section{$I V B$. Identification of mitochondrially synthesized subunits}

A selective labelling of mitochondrial or extramitochondrial translation products can be achieved by incorporation in vivo of radioactive amino acids in the presence of specific inhibitors of cytoplasmic (cycloheximide) or mitochondrial (chloramphenicol) protein synthesis $[16,17,20]$. Such labelling experiments, however, are hampered by the fact that polypeptides synthesized in the presence of either inhibitor are not or only partially assembled into functional enzymes. This pertains not only to the ATPase complex (see below) but also to cytochrome oxidase [20,56,67] and cytochrome $b c_{1}$ [68].

In pioneering experiments Tzagoloff and Meagher identified four mitochondrially synthesized polypeptides in oligomycin-sensitive ATPase from yeast [51]. The incorporation in vivo of radioactive amino acids was performed in the same experimental system as was used during the studies on the biogenesis of the membrane factor (see section IIIB). Repressed cells were incubated for $6 \mathrm{~h}$ in a low-glucose medium containing chloramphenicol. They were then transferred to a medium containing cycloheximide and radioactive leucine and aerated for another $17 \mathrm{~h}$. As described in section IIIB and in Scheme 1, oligomycin-sensitive ATPase is not assembled under these conditions. Thus, special techniques had to be applied in order to detect mitochondrial products:

(1) Antiserum to whole oligomycin-sensitive ATPase precipitated four polypeptides labelled in the presence of cycloheximide. Apparently, these antibodies also recognized free (i.e. not assembled) components.

(2) The ATPase complex was reconstituted in vitro starting with membranes labelled in the presence of cycloheximide. After the in vitro 'assembly' the same four mitochondrially synthesized polypeptides could be detected in functional oligomy- 
cin-sensitive ATPase as well as in an immunoprecipitate obtained with antiserum to $\mathrm{F}_{1}$.

In these experiments the bulk of cycloheximide-resistant label (about $80 \%$ ) was found in a low molecular weight product which migrated with the smallest subunit of the ATPase complex (7500 daltons). Three other radioactivity peaks were correlated with the subunits of 29000,22000 and 12000 daltons [51]. These results suggested that all four subunits of the membrane factor are synthesized on mitochondrial ribosomes [69].

Ebner and Schatz reported that in derepressed yeast under the action of cycloheximide four polypeptides were synthesized which could be precipitated with antiserum to $F_{1}$ [70]. These mitochondrial translation products exhibited apparent molecular weights of $37500,30500,17500$ and less than 10000 . These authors did not correlate the polypeptides with subunits of the ATPase complex [71]. It is unclear how they can be correlated with the mitochondrially synthesized polypeptides described by Tzagoloff and Meagher [51].

Jackl and Sebald studied amino acid incorporation into the ATPase complex from $N$. crassa [43]. In the experiments described in Figs. 3 and 4, the ATPase polypeptides were isolated by immunoprecipitation with antiserum to $F_{1}$ and then separated by gel electrophoresis. Throughout the experiments proteins were double-labelled. $\left[{ }^{14} \mathrm{C}\right]$ leucine was added for three hours to exponentially growing cells. All proteins were thereby labelled according to their leucine contents [56]. Thereafter $\left[{ }^{3} \mathrm{H}\right]$ leucine was added to the cultures after inhibition of either cytoplasmic (Fig. 3) or mitochondrial (Fig. 4) protein synthesis. Polypeptides synthesized and labelled in the presence of either cycloheximide or chloramphenicol could thus be immediately related to the ${ }^{14} \mathrm{C}$ control label.

A pulse of $\left[{ }^{3} \mathrm{H}\right]$ leucine incorporated in the presence of cycloheximide resulted in the labelling of only two polypeptides which migrated with the ATPase subunits of 19000 and 11000 daltons (Fig. 3C). In the large polypeptide the cycloheximideresistant label was found to be enriched about 4-fold. In the smaller polypeptide the ${ }^{3} \mathrm{H}$ radioactivity did not exactly coincide with the ${ }^{14} \mathrm{C}$ protein label and was not as clearly enriched. This may be explained by the incomplete separation of this component from the 12000 -dalton subunit during gel electrophoresis, since the purified polypeptide exhibited a higher ${ }^{3} \mathrm{H} /{ }^{14} \mathrm{C}$ ratio (see Fig. 9 in section IVE).

A significant amount of labelled mitochondrial products could be recovered in the ATPase complex only when the cells had been preincubated with chloramphenicol. Moreover, the proportion of mitochondrial label appearing in the ATPase complex was higher after a labelling period of 2 min plus a 60 -min chase (Fig. 3C) than after a labelling period of $60 \mathrm{~min}$ (Fig. 3B). Without the transitory incubation of the cells with chloramphenicol, low and varying amounts of cycloheximideresistant label were detected in the ATPase complex (Fig. 3A). These results suggest that even in short term experiments the assembly of the ATPase complex is inhibited by cycloheximide (see section IIIC). The inhibition, however, is not as pronounced as in the long term experiments performed with derepressing yeast [51]. 


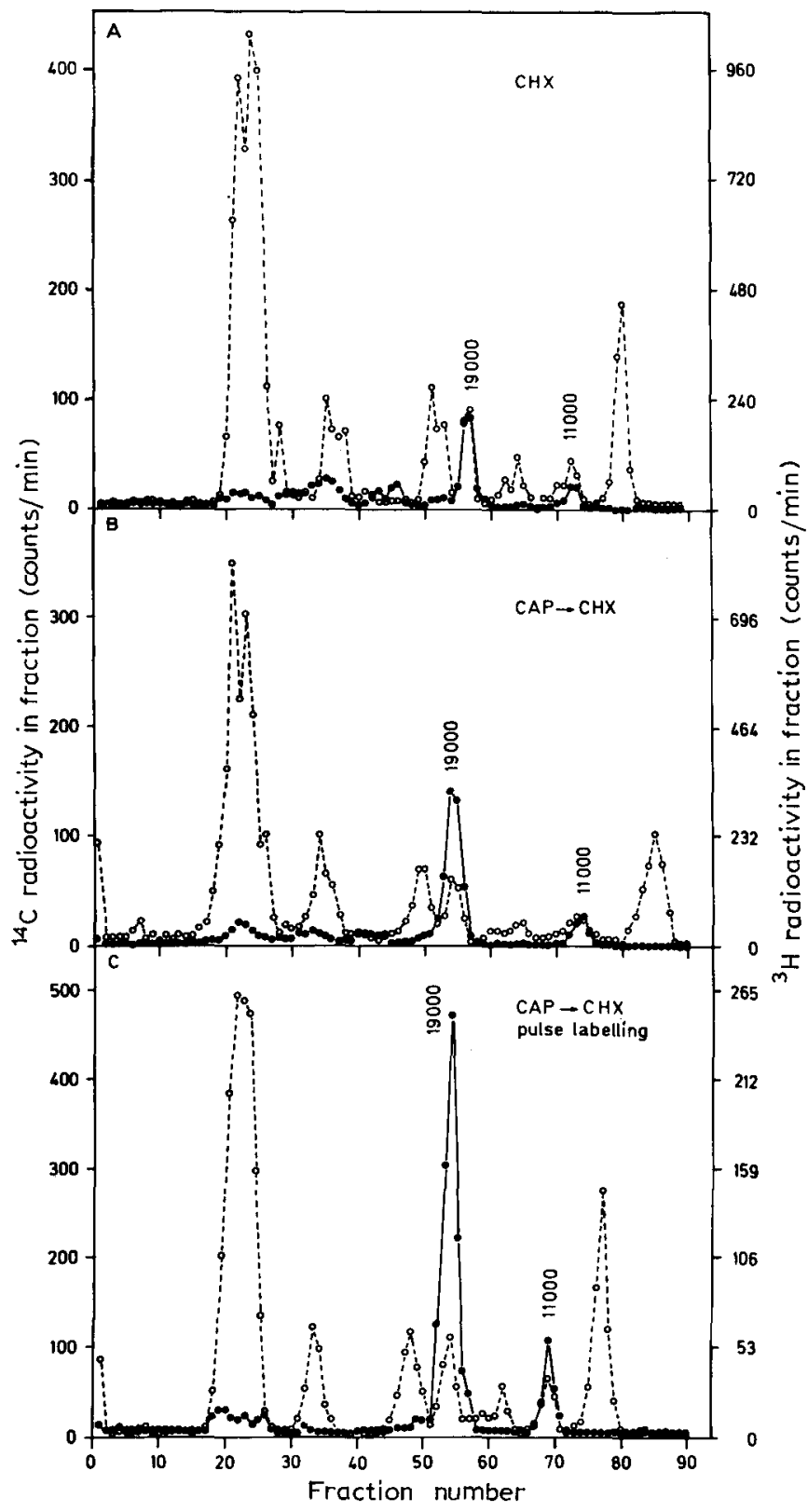

Fig. 3. Cycloheximide-resistant label in immunoprecipitated ATPase complex after different labelling procedures ( N. crassa). $0--\mathrm{O},\left[{ }^{14} \mathrm{C}\right]$ leucine control label; $-\mathbf{0},\left[{ }^{3} \mathrm{H}\right]$ leucine incorporated in the presence of cycloheximide (A) over a labelling period of $60 \mathrm{~min}$, (B) over a labelling period of $60 \mathrm{~min}$ after a transitory incubation with chloramphenicol and (C) over a labelling period of $2 \mathrm{~min}$ plus a $60 \mathrm{~min}$ chase after a transitory incubation with chloramphenicol. The ATPase complex was isolated by immunoprecipitation with antiserum to $F_{1}$ and separated by dodecyl sulfate gel electrophoresis. The scales of the ${ }^{3} \mathrm{H}$ and ${ }^{14} \mathrm{C}$ radioactivities in the ordinates were drawn in the same relations as the ${ }^{3} \mathrm{H} /{ }^{14} \mathrm{C}$ ratios determined for whole mitochondrial protein (A: $2.4 ; \mathrm{B}: 2.32 ; \mathrm{C}: 0.53$ ). For experimental details see ref. 43. CAP, chloramphenicol; $\mathrm{CHX}$, cycloheximide. 


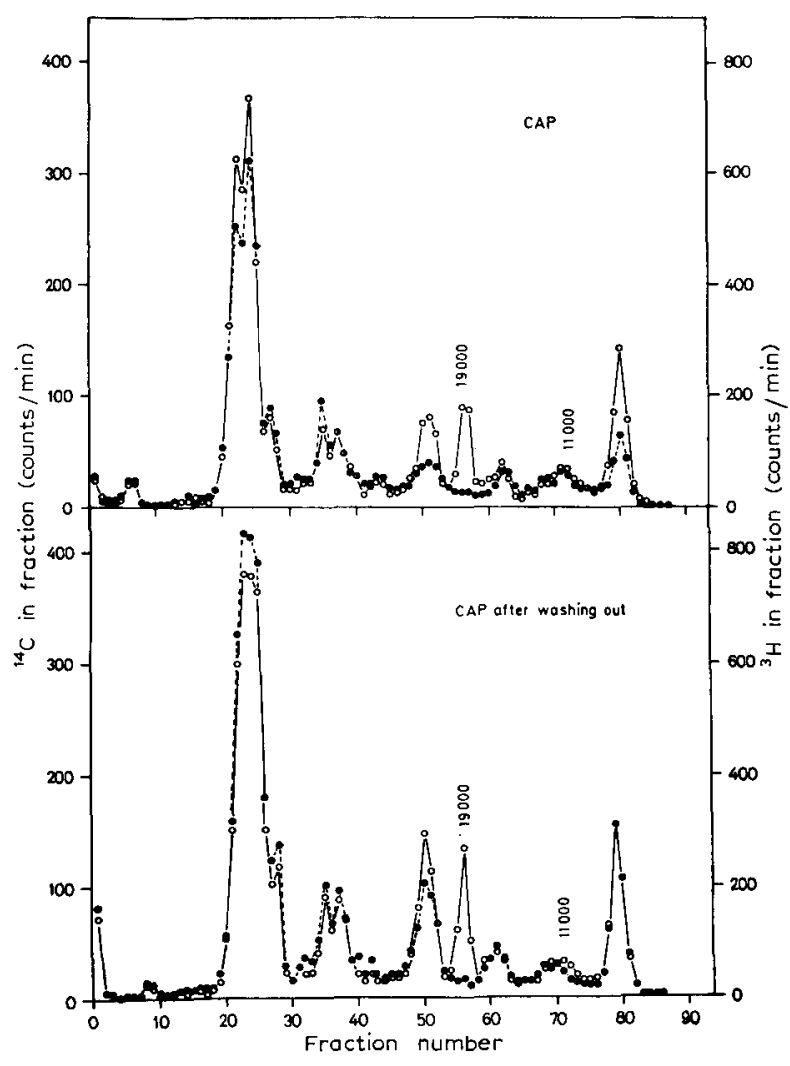

Fig. 4. Recovery of chloramphenicol-resistant label in immunoprecipitated ATPase complex before and after washing out the inhibitor $\left(N\right.$. crassa), $O-O,\left[{ }^{14} \mathrm{C}\right]$ leucine control label; $0-0\left[{ }^{3} \mathrm{H}\right]$ leucine incorporated during a 30 -min labelling period in the presence of chloramphenicol (A) before and (B) after washing-out of chloramphenicol and further growth of the cells. The ATPase complex was isolated by immunoprecipitation with antiserum to $\mathbf{F}_{\mathbf{1}}$ and separated by dodecyl sulfate gel electrophoresis. The scales of the ${ }^{3} \mathrm{H}$ and ${ }^{14} \mathrm{C}$ radioactivities in the ordinates were drawn in the same relations as the ${ }^{3} \mathrm{H} /{ }^{14} \mathrm{C}$ ratios determined for whole mitochondrial protein (A and $\mathrm{B}, 2.0$ ). For experimental details see ref. 43. CAP, chloramphenicol.

After inhibiton of mitochondrial protein synthesis by chloramphenicol $\left[{ }^{3} \mathrm{H}\right]$ leucine was incorporated into all polypeptides of ATPase complex with the exception of the components of 19000 and 11000 daltons. In the case of these two polypeptides an inhibition of labelling of $90 \%$ and $50 \%$ respectively persisted even after removal of chloramphenicol and further growth of the cells (Fig. 4B). The label increased in some other polypeptides after washing out the chloramphenicol. Most probably, these polypeptides were synthesized in the presence of chloramphenicol but not assembled into the ATPase complex until mitochondrial protein synthesis had been restored.

Thus labelling experiments performed in the presence of cycloheximide and chloramphenicol yielded consistent results: In the Neurospora ATPase complex only 


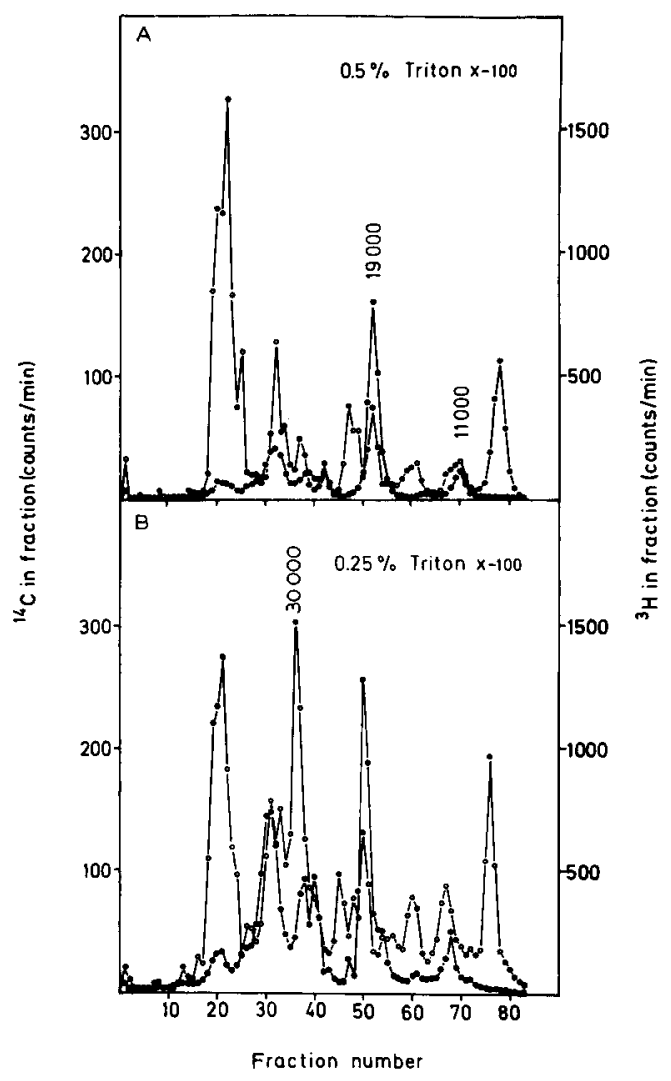

Fig. 5. Polypeptide patterns of ATPase complexes immunoprecipitated with antiserum to $F_{1}$ from mitochondria dissolved at $0.5 \%$ (A) and $0.25 \%$ (B) Triton X-100. The polypeptides were separated by dodecyl sulfate gel electrophoresis. $\bigcirc-\bigcirc\left[{ }^{14} \mathrm{C}\right]$ leucine control label; $-\mathbf{0},\left[{ }^{3} \mathrm{H}\right]$ leucine incorporated over a labelling period of $60 \mathrm{~min}$ in the presence of cycloheximide after a transitory incubation of the cells with chloramphenicol. For experimental details see ref. 40.

the polypeptides of 19000 and 11000 daltons are synthesized on mitochondrial ribosomes, whereas all other polypeptides are provided by the cytoplasmic system.

The two mitochondrially synthesized polypeptides of Neurospora ATPase may be analogous to the yeast polypeptides of 22000 and 12000 daltons which were detected by Tzagoloff and Meagher. The two other mitochondrial translation products of 29000 and 7500 daltons present in the yeast ATPase complex, however, have no counterparts in the Neurospora enzyme.

One possible explanation for this discrepancy might be that in $N$. crassa some mitochondrial products are only weakly bound to the ATPase complex. The presence or absence of these polypeptides could depend on the conditions used for the isolation of the enzyme protein. In the experiments described above in Figs. 3 and 4, the 
ATPase complex was solubilized and immunoprecipitated at fairly high concentrations of Triton X-100 $(1 \%)$ and $\mathrm{KCl}(0.3 \mathrm{M})$. As shown in Fig. 5A, nearly the same polypeptide pattern could be observed when the complex was isolated in the presence of only $0.5 \%$ Triton X-100 and in the absence of salt. However, when the concentration of the detergent was decreased still further to $0.25 \%$, additional polypeptides appeared to be associated with the ATPase complex (Fig. 5B). The homogeneous protein label now showed a large amount of a polypeptide with a molecular weight of 30000 daltons. This polypeptide did not exactly coincide with the cycloheximideresistant label present at this molecular weight range. It exhibited, however, an electrophoretic mobility very similar to the ADP/ATP carrier from $N$. crassa (Sebald, Hackenberg and Klingenberg; unpublished results). The mitochondrial translation products associated with this immunoprecipitated ATPase complex exhibited a distribution similar to that observed with whole mitochondrial protein [56]. The $19000-$ and 11000 -dalton polypeptide predominated somewhat. Even under these conditions no cycloheximide-resistant label was found to migrate with the subunit of 8000 daltons.

In spite of the great differences observed in the polypeptide composition of the two immunoprecipitated proteins, nearly the same cold-stable and oligomycinsensitive ATPase activity was measured when mitochondria were dissolved with $0.5 \%$ and $0.25 \%$ Tirton X-100 (Table II). This suggested that the additional polypeptides are not essential for the function of oligomycin-sensitive ATPase in $N$. crassa.

\section{IVC. Assembly}

The assembly of mitochondrial ATPase as a multi-polypeptide complex is necessarily a multi-step process. Consequently, the ATPase polypeptides, when

\section{TABLE II}

INFLUENCE OF DIFFERENT CONCENTRATIONS OF TRITON X-100 ON OLIGOMYCINSENSITIVITY OF MITOCHONDRIAL ATPase FROM NEUROSPORA CRASSA

Mitochondria were incubated for $10 \mathrm{~min}$ without and with oligomycin ( $4 \mu \mathrm{g}$ per $\mathrm{mg}$ protein). They were then dissolved at a concentration of $2 \mathrm{mg}$ protein per $\mathrm{ml}$ with the indicated amounts of Triton $\mathrm{X}-100$ in $10 \mathrm{mM}$ Tris, $\mathrm{pH}$ 7.2. ATPase activities were measured after an incubation for $4 \mathrm{~h}$ at $0{ }^{\circ} \mathrm{C}$.

\begin{tabular}{lll}
$\begin{array}{l}\text { Concentration } \\
\text { of Triton X-100 } \\
(\%, w / v)\end{array}$ & $\begin{array}{l}\text { ATPase activity } \\
\text { without oligomycin } \\
\left(\mu \mathrm{mol} \mathbf{P}_{1} \cdot \mathrm{min}^{-1} \cdot \mathrm{mg}^{-1}\right)\end{array}$ & $\begin{array}{l}\text { Inhibition } \\
\text { by oligomycin } \\
(\%)\end{array}$ \\
\hline 0.1 & 1.9 & 83 \\
0.25 & 1.95 & 82 \\
0.5 & 1.85 & 76 \\
0.75 & 1.85 & 71 \\
1.0 & 1.9 & 64 \\
1.5 & 1.85 & 46 \\
2.0 & 1.95 & 21 \\
\hline
\end{tabular}




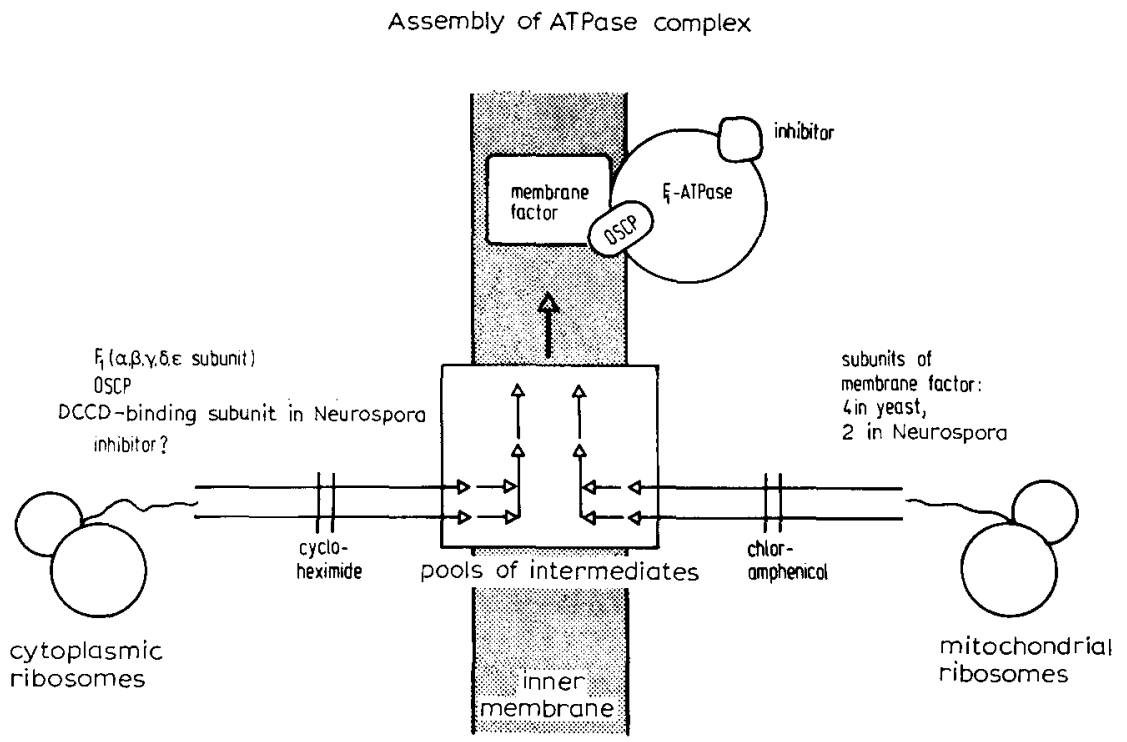

Scheme 2. Assembly of ATPase complex. The site of synthesis of the individual polypeptides is summarized according to the experimental results discussed in sections IIIA, IIIB, IVB and IVD.

released from the ribosomes, first enter pools of intermediates (Scheme 2). These intermediates may be free or partially assembled subunits. The functional enzyme is assembled from the pools of intermediates.

These pools became apparent in amino acid pulse-labelling experiments with exponentially growing cells of $N$. crassa. Newly synthesized pulse-labelled polypeptides appeared more slowly in the ATPase complex than in whole mitochondrial protein (Fig. 6). A similar delay in the labelling of cytochrome oxidase has already been published [72].

The existence of pools of intermediates also explains the labelling experiments in the presence of cycloheximide and chloramphenicol. Polypeptides synthesized and labelled in the presence of either inhibitor are detected in ATPase complex only when they can combine with a pool of those intermediates whose synthesis is interrupted.

In the case of Neurospora ATPase the limiting pools may only be small since even in short term experiments incomplete labelling patterns were observed under the action of either cycloheximide or chloramphenicol (see Figs. 3A and 4A). On the other hand, cycloheximide-resistant labelling of ATPase subunits could be increased by a transitory incubation of the cells with chloramphenicol (see Fig. 3B,C). This could have two reasons:

(1) In the presence of chloramphenicol the pools of the cytoplasmically synthesized subunits may be increased. A longer assembly of the ATPase complex is therefore possible in the presence of cycloheximide. 


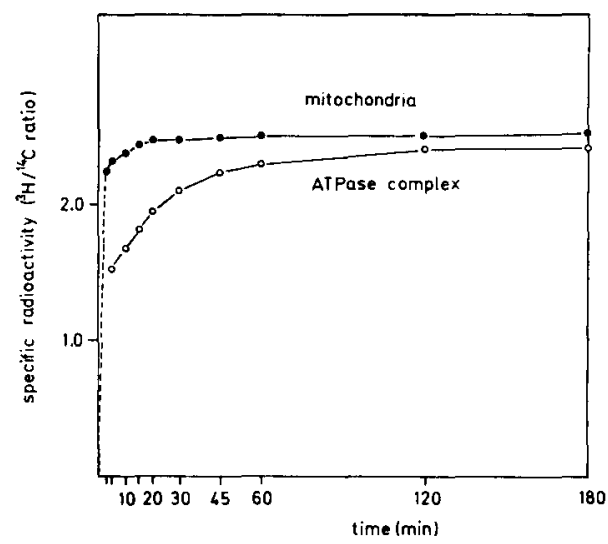

Fig. 6. Time-course of labelling of total mitochondrial protein (-) and of ATPase complex $(\mathrm{O}-\mathrm{O})$ in $N$. crassa. $\left[{ }^{14} \mathrm{C}\right]$ leucine was added to exponentially growing cells and $180 \mathrm{~min}$ later $\left[{ }^{3} \mathrm{H}\right]-$ leucine was added. After addition of the $\left[{ }^{3} \mathrm{H}\right]$ leucine, aliquots of the cells were frozen with liquid nitrogen at the time intervals indizated in the abscissa. Mitochondria were isolated from the frozen samples, and ATPase complex was iminunoprecipitated with antiserum to $F_{1}$. Similar experiments have been performed with cytochrome oxidase and the experimental details are there described [72].

(2) The pools of the mitochondrially synthesized subunits may decrease during the chloramphenicol treatment and therefore the polypeptides synthesized in the presence of cycloheximide appear more rapidly in the ATPase complex.

In derepressing yeast a quantitative relation was observed between the time of chloramphenicol preincubation and the amount of ATPase membrane factor which was assembled in the presence of cycloheximide [12]. Parallel to this, the rate and total amount of cycloheximide-resistant amino acid incorporation into the mitochondrial membrane protein was found to be enhanced [12]. During the discussion of these results the possibility was considered that assembly and synthesis of mitochondrial translation products are interdependent processes. The mitochondrial protein synthesis might only function to complete the assembly of proteins which are in part made by the cytoplasmic system [1]. This consideration, however, seems not to be convincing for two reasons:

(1) It was reported that cycloheximide-resistant amino acid incorporation is enhanced greatly in yeast during glucose derepression [73]. The stimulation of mitochondrial protein synthesis by preincubation with chloramphenicol could thus merely indicate that the induction of mitochondrial protein synthesis proceeds also in the presence of chloramphenicol.

(2) It seems unclear how cycloheximide-resistant synthesis and assembly of a mitochondrially made membrane factor can be stimulated by an $F_{1}$ and OSCP which are supposed to accumulate outside the mitochondria during the chloramphenicol treatment. Whole ologomycin-sensitive ATPase was not assembled under these conditions (see Scheme 1). 
At the present time, the nature and the sequence of the intermediates occurring in the assembly of mitochondrial ATPase are still unknown. It has been discussed that a steady state pool of free $F_{1}$ exists outside the mitochondria, and that the $F_{1}$ intermediate (together with free OSCP) awaits synthesis of mitochondrial products before it can be integrated into the membrane to form whole oligomycin-sensitive ATPase [33]. This discussion is based on the observation that repressed yeast cells which are incubated with chloramphenicol on a low-glucose medium accumulate large amounts of $F_{1}$ which are recovered after cell breakage in the postribosomal supernatant. After removal of chloramphenicol and further growth of the cells, the accumulated $F_{1}$ was found to be partially assembled into functional oligomycinsensitive ATPase [33]. Thus the in vivo assembly might be similar to the in vitro reconstitution of the enzyme complex.

However, it is questionable if, in the absence of mitochondrial protein synthesis, free $F_{1}$ accumulates outside the mitochondria. Several laboratories reported that $F_{1}$ was present in mitochondria isolated from cytoplasmic petite mutants of yeast [30-32]. It is unclear how $F_{1}$ is bound to the mutant mitochondria. But an intermediate containing $F_{1}$ and accumulated in the membrane in the absence of mitochondrial protein synthesis, may be labile to such an extent that free $F_{1}$ is split off during the isolation of the mitochondria.

\section{IVD. Isolated hydrophobic subunits}

Polypeptides of low molecular weight which are soluble in organic solvents but insoluble in water have been isolated from the ATPase complex of several organisms. They have been referred to as "proteolipids" (Folch and Lees [74]) even though the presence of lipid components has not been established in these proteins up to now.

The mitochondrially synthesized subunit of 7500 dalton was predominantly extracted by neutral chloroform/methanol from yeast ATPase [75]. The extracted polypeptide could be separated from minor contaminants by thin-layer chromatography and then migrated as single band on dodecyl sulfate gels. Amino acid analysis of the purified protein revealed an extremely high percentage of hydrophobic residues (Table III). A polarity of only $24 \%$ was calculated using the formula proposed by Capaldi and Vanderkooi [76]. A proteolipid which is probably identical with the ATPase subunit was isolated by the same procedure from whole submitochondrial particles $[75,77]$.

The mitochondrial proteolipid from yeast shows an unusual property in that it is recovered in a high-molecular-weight form of 45000 daltons when ATPase complex or submitochondrial particles are separated by dodecyl sulfate gel electrophoresis. The large protein is converted to the low-molecular-weight species of 7500 daltons when ATPase complex or submitochondrial particles are exposed to alkaline conditions or to organic solvents [75,77]. It is still unknown whether the high-molecular-weight species represents a polymer or a complex with another component. In certain ATPase mutants the proteolipid was found either to be absent [78] or only to be present in the low-molecular-weight form [79]. 


\section{TABLE III}

AMINO ACID COMPOSITION OF HYDROPHOBIC POLYPEPTIDES ISOLATED FROM OLIGOMYCIN-SENSITIVE ATPase

The polypeptide from $S$. cerevisiae has been analysed by Sierra and Tzagoloff [75]. The polypeptides isolated from $N$. crassa are described in the legend to Fig. 8.

\begin{tabular}{|c|c|c|c|c|}
\hline \multirow[t]{2}{*}{ Amino acid } & \multicolumn{4}{|c|}{ Amount in polypeptides $(\mathrm{mol} / 100 \mathrm{~mol})$ with apparent molecular weights of: } \\
\hline & $\begin{array}{l}7500 \\
\text { (S.cerevisae) }\end{array}$ & $\begin{array}{l}8000 \\
(N . c r a s s a)\end{array}$ & $\begin{array}{l}11000^{*} \\
\text { (N.crassa) }\end{array}$ & $\begin{array}{l}19000 \\
\text { (N.crassa) }\end{array}$ \\
\hline Aspartic acid & 4.7 & 5.53 & 5.13 & 7.1 \\
\hline Threonine & 4.6 & 2.23 & 4.15 & 4.75 \\
\hline Serine & 6.9 & 9.61 & 11.2 & 9.06 \\
\hline Glutamic acid & 3.1 & 6.52 & 5.23 & 6.05 \\
\hline Proline & 3.1 & Trace & 7.21 & 4.01 \\
\hline Glycine & 14.2 & 15.3 & 2.71 & 8.01 \\
\hline Alanine & 13.4 & 16.8 & 2.18 & 7.86 \\
\hline Cysteine & n.d. & n.d. & n.d. & n.d. \\
\hline Valine & 7.5 & 7.57 & 7.59 & 4.56 \\
\hline Methionine & 3.1 & 2.64 & 1.27 & 1.08 \\
\hline Isoleucine & 10.9 & 7.17 & 9.28 & 11.9 \\
\hline Leucine & 15.5 & 12.0 & 13.8 & 16.6 \\
\hline Tyrosine & 1 & 2.69 & 4.24 & 3.05 \\
\hline Phenylalanine & 7.2 & 7.19 & 12.5 & 9.63 \\
\hline Lysine & 3.4 & 2.45 & 7.32 & 1.41 \\
\hline Histidine & Trace & Trace & Trace & 2.55 \\
\hline Arginine & 1.5 & 2.27 & 6.16 & 2.48 \\
\hline Tryptophan & n.d. & n.d. & n.d. & n.d. \\
\hline Polarity** & $24.2 \%$ & $28.6 \%$ & $39.2 \%$ & $33.4 \%$ \\
\hline
\end{tabular}

* Contaminated by the polypeptide of 8000 daltons.

${ }^{* *}$ Calculated according to Capaldi and Vanderkooi [76]. Tryptophan and cysteine which were not determined are not included in the calculation of these values.

That the proteolipid from yeast ATPase corresponds to the DCCD-binding protein identified in beef heart mitochondria has been discussed. As established with beef heart mitochondria, DCCD - like oligomycin - inhibits mitochondrial ATPase by binding to the membrane factor $[80,81]$. Studies with $\left[{ }^{14} \mathrm{C}\right] \mathrm{DCCD}$ showed that the inhibitor reacts irreversibly and probably covalently with primarily one polypeptide of low molecular weight [82]. The DCCD-binding protein could be separated from whole mitochondrial membranes [82] as well as from oligomycinsensitive ATPase [54] by extraction with neutral chloroform/methanol.

Recent studies led to the identification of a DCCD-binding protein in ATPase complex from $N$. crassa [40]. Membrane bound ATPase from this organism could be inhibited half-maximally using $0.5-1 \mu \mathrm{g}$ DCCD per mg protein. After incubation of mitochondria with $\left[{ }^{14} \mathrm{C}\right] \mathrm{DCCD}$ large part of the bound label was recovered in the ATPase complex. After gelelectrophoretic separation of the ATPase polypeptides, the ${ }^{14} \mathrm{C}$ radioactivity was found in one peak which migrated with the subunit fraction of 8000 daltons (Fig. 7A). Neutral chloroform/methanol extracted the 


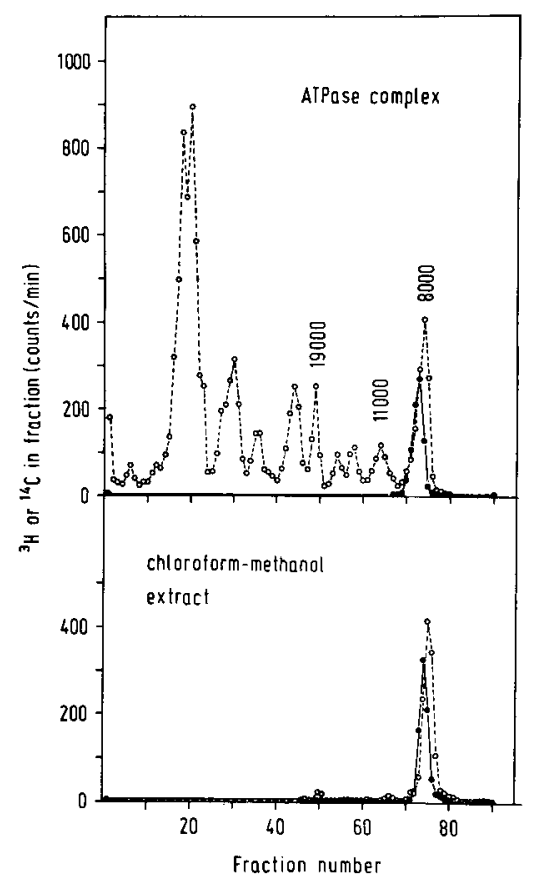

Fig. 7. Identification of a DCCD-binding protein in ATPase complex of $N$. crassa. Mitochondria labelled homogeneously with $\left[{ }^{3} \mathrm{H}\right]$ leucine $(345000 \mathrm{cpm}$ per $\mathrm{mg}$ protein) were incubated for $4 \mathrm{~h}$ at $0{ }^{\circ} \mathrm{C}$ with $2 \mu \mathrm{g}\left[{ }^{14} \mathrm{C}\right] \mathrm{DCCD}(20 \mathrm{mCi}$ per $\mathrm{mmol})$ per $\mathrm{mg}$ protein. The ATPase complex was then isolated by immunoprecipitation in the presence of $0.5 \%$ Triton $\mathrm{X}-100$ [43]. The precipitate was washed three times with $10 \mathrm{mM}$ Tris, $\mathrm{pH} 7.2$, and thereafter separated by electrophoresis on dodecyl sulfate gels. An aliquot of the immunoprecipitate was extracted with neutral chloroform/methanol $(2: 1 ; \mathrm{v} / \mathrm{v})$. The extracted protein was precipitated with 4 vols. of diethylether [82] and then dissolved again in chloroform/methanol. This was repeated three times. $5 \%$ of the ${ }^{3} \mathrm{H}$ protein label $(\mathrm{O}-\mathrm{O})$ and $50 \%$ of the $\left[{ }^{14} \mathrm{C}\right] \mathrm{DCCD}$ label $(\bullet)$ were recovered.

protein of 8000 daltons together with the DCCD label (Fig. 7B). Separations of double-labelled protein revealed that in whole ATPase complex as well as in the chloroform/methanol-soluble fraction the $\left[{ }^{14} \mathrm{C}\right] \mathrm{DCCD}$ label did not exactly coincide with the $\left[{ }^{3} \mathrm{H}\right]$ protein label. This suggested that in addition to the DCCD-binding protein other low molecular weight polypeptides are present or that the electrophoretic mobility is changed by the bound inhibitor.

In contrast to the mitochondrial proteolipid from yeast the polypeptide fraction of 8000 daltons present in Neurospora ATPase is not synthesized in the presence of cycloheximide. Also no mitochondrial translation product of this molecular weight appeared after exposure of mitochondrial or ATPase protein to alkali or chloroform/methanol. Contrarily, the subunit fraction of 8000 daltons was found to be highly labelled after amino acid incorporation in the presence of chloramphenicol (see Fig. 4B). According to these criteria the proteolipid fraction including the DCCD-binding protein is synthesized in $N$. crassa on cytoplasmic 


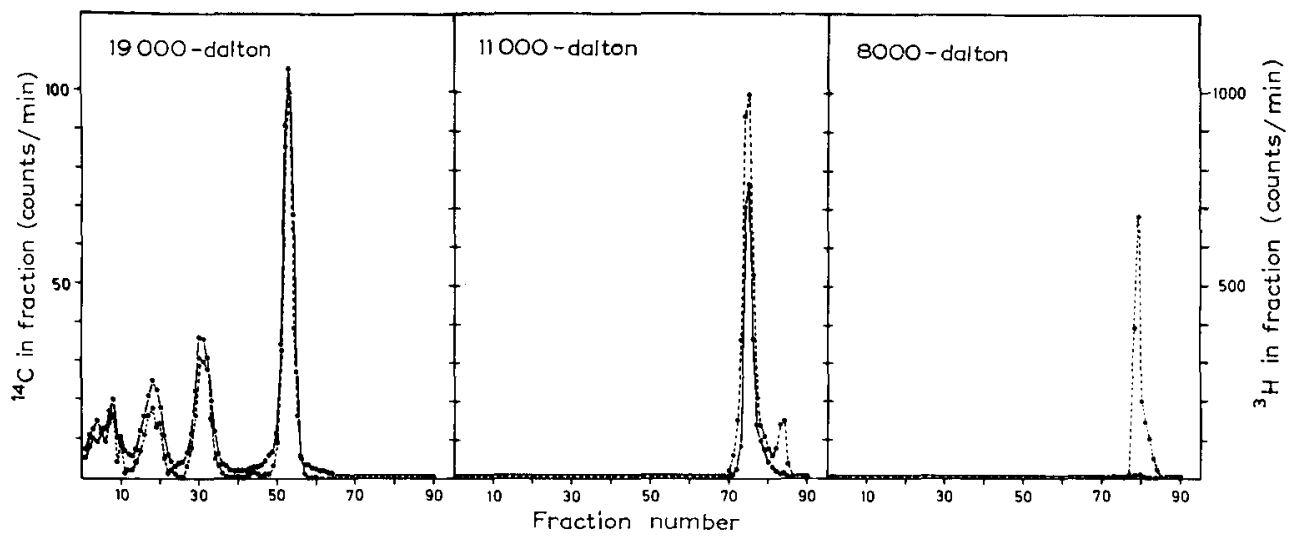

Fig. 8. Hydrophobic polypeptides purified from ATPase complex of $N$. crassa. The ATPase complex was isolated by immunoprecipitation with antiserum to $F_{1}$ [43]. The polypeptides were dissolved in dodecyl sulfate buffer and subjected to chromatography on Sephadex G-100 [111]. The 8000-dalton component was thereby obtained in pure form. Two othe $i$ chromatographic fractions containing the mitochondrial translation products were further separated by preparative dodecyl sulfate gel electrophoresis [56]. This yielded the preparation of the 19000 -dalton polypeptide shown in the figure. The 11000 -dalton polypeptide could be further purified by extraction with acidic chloroform/methanol. The final product was still contaminated by the protein of 8000 daltons. $\bigcirc--\bigcirc,\left[{ }^{14} \mathrm{C}\right]$ leucine control label: - $\left[{ }^{3} \mathrm{H}\right]$ leucine incorporated in the presence of cycloheximide after a transitory incubation with chloramphenicol (see Fig. 3B).

ribosomes. It is premature to assume that the translational origin of homologous proteolipids is different in yeast and Neurospora, since the homogeneity of these proteins has not been rigorously established up to now.

Three hydrophobic polypeptides could be isolated from immunoprecipitated ATPase complex of $N$. crassa after dissociation of the protein with dodecyl sulfate: the two mitochondrially synthesized polypeptides of 19000 and 11000 daltons and the cytoplasmically made protein of 8000 daltons. The polypeptides described in Fig. 8 were obtained from double-labelled ATPase, which contained a homogeneous $\left[{ }^{14} \mathrm{C}\right]$ leucine label and a $\left[{ }^{3} \mathrm{H}\right]$ leucine label incorporated in the presence of cycloheximide. Both labels were found to comigrate after dodecyl sulfate gel electrophoresis of the isolated mitochondrial translation products of 19000 and 11000 daltons. The larger polypeptide exhibited a great tendency to aggregate and the polymers could not be dissociated by treatment with alkali or disulfide-reducing agents. However, only one peak was observed after electrophoresis on phenol/formic acid gels [56] (Sebald; unpublished data). Amino acid analysis revealed a polarity of only $33 \%$ (TableIII). The low amounts of basic amino acids may explain why this polypeptide stains poorly with Coomassie Blue (see Figs. 1 and 2). The amino acid composition differs from that of the mitochondrially synthesized subunit III of cytochrome oxidase [56].

Both polypeptides exhibit a similar electrophoretic mobility on dodecyl sulfate gels [43].

In the smaller polypeptide of 11000 daltons the basic amino acids prevail over 
the acidic ones (Table III). A polarity of $39 \%$ is calculated from the amino acid composition. This is relatively high but still lower than the polarity of the watersoluble components ( $F_{1}, \mathrm{OSCP}$ and $\mathrm{F}_{1}$-inhibitor) of the ATPase complex [52,60, $83-85]$. The cytoplasmically synthesized protein of 8000 daltons, which is probably identical with the proteolipid (see above), was found to contain only $29 \%$ polar amino acids. This is less than in the two mitochondrial translation products.

\section{ATPase MUTANTS}

\section{VA. Cytoplasmic mutants}

The cytoplasmic mutants in $S$. cerevisiae have been classified into three groups:

(1) The cytoplasmic petite mutants [86] are characterized by large deletions $\left(\rho^{-}\right)$or even absence $\left(\rho^{0}\right)$ of mitochondrial DNA [87-89]. They are unable to perform mitochondrial protein synthesis since the genes for the ribosomal RNAs and/or the transfer RNAs are missing. Consequently, all proteins present in these mutants are identified as products of the cytoplasmic system.

As described in section III, the presence of $F_{1}$ could be demonstrated in these mutants. It is unknown whether OSCP is synthesized. A functional ATPase membrane factor is absent as indicated by the oligomycin-insensitivity of mitochondrial ATPase. This is further indicated by the observation that mitochondrial membranes of the mutants are unable to catalyze $P_{i}$-ATP exchange. These membranes cannot be energized by ATP and are rather impermeable to protons [90].

The question may be raised whether the $F_{1}$ in these cells still exerts some vital function. It is possibly relevant in this connection that cytoplasmic petite cells no longer grow when a second mutation is introduced (pet 936) leading to the loss of $F_{1}$ subunits [71].

(2) The mit $t^{-}$mutants $[91,92]$ are unable to grow on nonfermentable carbon sources but have retained a functional mitochondrial protein synthesizing system $[93,94]$.

One mit $^{-}$mutant was isolated which showed specific lesions in the mitochondrial ATPase [94]. In the mitochondrial fraction no ATPase activity could be measured. The ATPase activity present in the postribosomal supernatant, however, could be inhibited by antiserum to $F_{1}$. Mitochondrial translation products as in the wild type were observed after gelelectrophoretic separation of mitochondria labelled in vivo by incorporation of $\left[{ }^{35} \mathrm{~S}\right]$ methionine in the presence of cycloheximide. It cannot be concluded from the described experiment whether or not minor components were absent. Presently, it cannot be decided whether the mutation resides in a structural gene for one of the mitochondrially synthesized ATPase subunits or in a regulatory gene involved in the synthesis and assembly of these subunits.

(3) Antibiotic resistant mutants $\left(A n t^{R}\right)$ define several loci on mitochondrial DNA that code for mitochondrial ribosomes, cytochromes (e.g. antimycin-resistant mutants) and for the ATPase complex. Oligomycin-resistant mutants with a cyto- 
plasmic mode of inheritance have been isolated by different laboratories [95-104]. Genetic analysis of numerous oligomycin-resistant strains revealed the presence of two genatically unlinked loci, OLI 1 and OLI $2[101,102]$. It was tentatively inferred that the two loci represent two distinct genes $[102,104]$. Later on, a third locus was identified, OLI 3, which is closely linked to OLI 1. Both may therefore be localized within the same cistron $[105,106]$.

In these mutants, ATPase activity of submitochondrial particles or even if the solubilized enzyme was found to be resistant to oligomycin [99,103-105] indicating that the ATPase complex has been modified by the mutation of mitochondrial DNA. By in vitro reconstitution experiments in reciprocal systems $\left(F_{1}\right.$, OSCP and membrane factor from either wild-type or mutant) this alteration was found to reside in the membrane factor $[103,104]$. Recently, the mitochondrially synthesized proteolipid of yeast ATPase was shown to be present only in the low molecular weight form in OLI 1 mutants isolated independently in different laboratories [79]. The OLI 2 mutants contained the proteolipid in the high-molecularweight form (see also section IVD). Hence, the mutations conferring resistance to oligomycin are probably in structural genes of some of the mitochondrially synthesized subunits of the ATPase complex.

Additionally, venturicidin and triethyltin were used to select ATPase mutants [105-107]. One group of venturicidin-reistant strains were cross-resistant to oligomycin in vivo and in vitro and mapped at the OLI 3 locus. One mutant was obtained resistant in vivo to only venturicidin. The mutation was found to be situated at mitochondrial locus OLI 1. Remarkably, in this mutant the ATPase activity was resistant to oligomycin but not to venturicidin. Thus the in vitro ATPase assay may not adequately reflect in vivo action of the antibiotic. A third group of venturicidinresistant mutants showed in vivo cross-resistance to triethyltin. Here again the resistance in vitro of mitochondrial ATPase was only ponrly expressed.

The determinants for this third group of venturicidin-resistant mutants may not be located on mitochondrial DNA [108]. It is at present under discussion that another cytoplasmic DNA species is involved which may have the properties of an episome. The intra-or extra-mitochondrial location of the postulated episomal system remains to be established.

\section{VB. Nuclear mutants}

Nuclear mutants with lesions of the ATPase complex have been isolated from Schizosaccharomyces pombe $[41,59,109]$ and $S$. cerevisiae $[71,78,110]$. All of them exhibited in addition to the defect of the ATPase highly reduced levels of respiratory enzymes. The pleiotropic phenotype, however, appears to result from single gene mutations.

Several of the mutants retained $F_{1}$ ATPase which was either recovered in the postribosomal supernatant [78] or was easily detached from the mitochondria [59]. At present it cannot be decided if the primary defects reside in genes of the ATPase complex. It has been discussed that genes are mutated specifying a central process 
regulating the synthesis or the assembly of the inner membrane enzymes $[59,110]$. In a mutant from $S$. cerevisiae, isolated by Tzagoloff et al. [78], the mitochondrially synthesized proteolipid could not be detected, whereas mitochondrially synthesized subunits of cytochrome oxidase and cytochrome $b c_{1}$ appeared to be present. This observation suggests a specific lesion of the ATPase complex.

In other nuclear mutants no $F_{1}$ ATPase could be found $[71,78,109,110]$. Ebner and Schatz established in extensive studies on one mutant from $S$. cerevisiae (pet 936) that at least the two large subunits of $F_{1}$ are absent [71]. It was speculated that the mutation is in a structural gene of one of these two polypeptides. Remarkably, this mutant cannot grow under anaerobic conditions. Thus, mitochondrial ATPase also appears to exert a vital function in the absence of electron flow.

\section{CONCLUDING REMARKS}

The results presented in this review clearly demonstrate that the biogenesis of mitochondrial ATPase depends on a close cooperation of mitochondrial and cytoplasmic protein synthesis. The polar constituents of the enzyme protein, i.e. the subunits of $F_{1}$ and most probably also OSCP and $F_{1}$-inhibitor, are formed on cytoplasmic ribosomes and imported into the mitochondria. Mitochondrially made hydrophobic polypeptides are integral constituents of the membrane factor.

In the author's opinion, however, the number of these mitochondrial translation products is not finally established. Whereas cytochrome oxidase as well as cytochrome $b c_{1}$ were found to contain the same set of mitochondrially synthesized polypeptides in yeast and $N$. crassa, the results obtained with mitochondrial ATPase are only partially in accordance. The difference is most striking in the case of the mitochondrial proteolipid. The possibility may be envisaged that this protein is synthesized in yeast inside and in Neurospora outside the mitochondria.

Probably, the mitochondrially made subunits of the ATPase complex are coded for by cytoplasmic genes. The identification and mapping of these genes may be expected in the near future. New cytoplasmic mutants are currently being isolated, and new techniques have been developed for genetic and physical mapping of mitochondrial DNA [112]. The assignment of structural genes to individual polypeptide chains, however, will presumably depend on the isolation of pure subunits and their chemical and immunological characterization.

\section{ACKNOWLEDGEMENT}

The author is grateful to Th. Bücher for helpful discussions. He thanks T. Harmey, G. von Jagow, D. Pfetscher, A. Schwab and S. Werner for help in preparing the manuscript. The work on the biogenesis of Neurospora ATPase was supported by the Deutsche Forschungsgemeinschaft, Sonderforschungsbereich 51, Medizinische Molekularbiologie und Biochemie. 


\section{REFERENCES}

1 Tzagoloff, A., Rubin, M. S. and Sierra, M. F. (1973) Biochim. Biophys. Acta 301, 71-104

2 Schatz, G. and Mason, T. L. (1974) Annu. Rev. Biochem. 43, 51-87

3 Kroon, A. M. and Saccone, C. (1974) Proceedings of the International Conference on the Biogenesis of Mitochondria, Bari, Italy Academic Press, New York

4 Lloyd, D. (1974) The Mitochondria of Microorganisms, Academic Press, New York

5 Kovać L. (1974) Biochim. Biophys. Acta 346, 101-135

6 Quagliariello, E., Papa, S., Palmieri, F., Slater, E. C. and Siliprandi, N. (1975) in Proceedings of the International Symposium on Electron Transfer Chains and Oxidative Phosphorylation, Selva di Fasano, Italy, North Holland Publishing Co., Amsterdam

7 Tzagoloff, A. (1975) Membrane Biogenesis, Plenum Press, New York

8 Senior, A. E. (1973) Biochim. Biophys. Acta 301, 249-277

9 Somlo, M. (1968) Eur. J. Biochem. 5, 276-284

10 Tzagoloff, A. (1969) J. Biol. Chem. 244, 5027-5033

11 Tzagoloff, A. (1970) J. Biol. Chem. 245, 1545-1551

12 Tzagoloff, A. (1971) J. Biol. Chem. 246, 3050-3056

$13 \mathrm{Kim}, \mathrm{I}-\mathrm{E}$. and Beattie, D. S. (1973) Eur. J. Biochem. 35, 509-518

14 Sisler, H. D. and Siegel, M. R. (1967) in Antibiotics, Mechanism of Action (Gottlieb, D. and Shaw, P. D., eds.), Vol. 1 p. 283, Springer Verlag, Berlin

15 Beattie, D. S. (1968) J. Biol. Chem. 243, 177-180

16 Sebald, W., Hofstötter, Th., Hacker, D. and Bücher, Th. (1969) FEBS Lett. 2, 177-180

17 Schatz, G. and Saltzgaber, J. (1969) Biochem. Biophys. Res. Commun. 37, 996-1001

18 Mager, J. (1960) Biochim. Biophys. Acta 38, 10-15

19 Clark-Walker, G. D. and Linnane, W. A. (1966) Biochem. Biophys. Res. Commun. 25, 8-13

20 Sebald, W., Weiss, H. and Jackl, G. (1972) Eur. J. Biochem. 30, 413-417

21 Pullman, M. E., Penefsky, H. S., Datta, A. and Racker, E. (1960) J. Biol. Chem. 235, 3322-3329

22 Penefsky, H. S., Pullman, M. E., Datta, A. and Racker, E. (1960) J. Biol. Chem. 235, 3330-3336

23 Mac Lennan, D. H. and Tzagoloff, A. (1968) Biochemistry 7, 1603-1610

24 Kagawa, Y. and Racker, E. (1966) J. Biol. Chem. 241, 2461-2466

25 Kagawa, Y. and Racker, E. (1971) J. Biol. Chem. 246, 5477-5487

26 Pullman, M. E. and Monroy, G. C. (1963) J. Biol. Chem. 238, 3762-3769

27 Schatz, G., Penefsky, H. S. and Racker, E. (1967) J. Biol. Chem. 242, 2552-2560

28 Ebner (1974) in Abstracts of the 9th Meeting of the Federation of European Biochemical Societies Budapest, 1974, Abstr. s6j3

29 Sartre, M., Jerphanion, M.-B., Huet, J. and Vignais, P. V. (1975) Biochim. Biophys. Acta 387, $241-255$

30 Kovać, L. and Weissova, K. (1968) Biochim. Biophys. Acta 153, 55-59

31 Schatz, G. (1968) J. Biol. Chem. 243, 2192-2199

32 Packer, L., Williams, M. A. and Criddle, R. S. (1973) Biochim. Biophys. Acta 292, 92-104

33 Tzagoloff, A., Akai, A. and Sierra, M. F. (1972) J. Biol. Chem. 247, 6511-6516

34 Groot, G. S. P. and Meyer, M. (1969) Biochim. Biophys. Acta 180, 575-577

35 Van de Stadt, R. J., Kraaipoel, R. J. and Van Dam, K. (1972) Biochim. Biophys. Acta 267, 25-36

36 Horstman, L. L. and Racker, E. (1970) J. Biol. Chem. 245, 1336-1344

37 Asami, K., Juntti, K. and Ernster, L. (1970) Biochim. Biophys. Acta 205, 307-311

38 Van de Stadt, R. J., de Boer, B. L. and Van Dam, K. (1973) Biochim. Biophys. Acta 292, 338-349

39 Tzagoloff, A. (1971) in Current Topics in Membrane and Transport (Bronner, F. and Kleinzeller, A., eds.), Vol. 2, pp. 157-205, Academic Press, New York

40 Sebald, W. and Jackl, G. (1975) in Electron Transfer Chains and Oxidative Phosphorylation (Quagliariello, E., Papa, S., Palmieri, F., Slater, E. C. and Siliprandi, N., eds.), pp. 193-198, North Holland Publishing Co., Amsterdam

41 Goffeau, A., Briquet, M., Colson, A. M., Delhez, J., Foury, F., Labaille, Y. and Mohar, O. (1975) in Membrane Biogenesis (Tzagoloff, A., ed.), pp. 63-97 Plenum Press, New York

42 Tzagoloff, A. and Meagher, P. (1971) J. Biol. Chem. 246, 7328-7336

43 Jackl, G. and Sebald, W. (1975) Eur. J. Biochem. 54, 97-106

44 Shapiro, A. L., Vinuela, E. and Maizel, J. V. (1967) Biochem. Biophys. Res. Commun. 28, 815-820

45 Weber, K. and Osborne, M. (1969) J. Biol. Chem. 244, 4406-4412 
46 Marjanen, L. A. and Ryrie, I. J. (1974) Biochim. Biophys. Acta 371, 442-450

47 Capaldi, R. A. (1973) Biochem. Biophys. Res. Commun. 54, 1331-1337

48 Swanljung, P., Frigeri, L., Ohlson, K. and Ernster, L. (1973) Biochim. Biophys. Acta 305, 519-533

49 Sadler, M. H., Hunter, D. R. and Haworth, R. A. (1974) Biochem. Biophys. Res. Commun. 59, 804-812

50 Serrano, R., Kanner, B. I. and Racker, E. (1976) J. Biol. Chem. 251, 2453-2461

51 Tzagoloff, A. and Meagher, P. (1972) J. Biol. Chem. 247, 594-603

52 Senior, A. E. (1971) J. Bioenerg. 2, 141-150

53 Kagawa, Y. and Racker, E. (1966) J. Biol. Chem. 241, 2467-2474

54 Stekhoven, F. S., Waitkus, R. F. and Van Moerkerk, T. B. (1972) Biochemistry 11, 1144-1150

55 Senior, A. E. and Brooks, J. C. (1971) FEBS Lett. 17, 327-329

56 Sebald, W., Machleidt, W. and Otto, J. (1973) Eur. J. Biochem. 38, 311-324

57 Mason, T. L., Poyton, R. O., Wharton, D. C. and Schatz, G. (1973) J. Biol. Chem. 248, 1346-1354

58 Rubin, M. S. and Tzagoloff, A. (1973) J. Biol. Chem. 248, 4269-4274

59 Goffeau, A., Landry, Y., Foury, M. and Colson, A. M. (1973) J. Biol. Chem. 248, 7097-7105

60 Brooks, J. C. and Senior, A. E. (1971) Arch. Biochem. Biophys. 147, 467-470

61 Ricchio, P., Aquila, H. and Klingenberg, M. (1975) FEBS Lett. 56, 133-138

62 Klingenberg, M., Aquila, H., Ricchio, P., Buchanan, B. B., Eierman, W. and Hackenberg, H. (1975) in Electron Transfer Chains and Oxidative Phosphorylation (Quagliariello, E., Papa, S., Palmieri, F., Slater, E. C. and Siliprandi, N., eds.), pp. 431-438, North Holland Publishing Co., Amsterdam

63 Ross, E. and Schatz, G. (1976) J. Biol. Chem. 251, 1991-1996

64 Michel, R., Liebl, A., Machleidt, W., Otto, J. and Neupert, W. (1975) Hoppe Seylers Z. Physiol. Chem. 356, 1595-1604

65 Senior, A. E. (1975) Biochemistry 14, 660-664

66 Vogel, G. and Steinhart, R. (1976) Biochemistry 15, 208-216

67 Mason, T. L. and Schatz, G. (1973) J. Biol. Chem. 248, 1355-1360

68 Katan, M. B. and Groot, G. S. P. (1975) in Electron Transfer Chains and Oxidative Phosphorylation (Quagliariello, E., Papa, S., Palmieri, F., Slater, E. C. and Siliprandi, N. eds.), pp. 127-132, North Holland Publishing Co., Amsterdam

69 Tzagoloff, A., Akai, A. and Rubin, M. S. (1974) in The Biogenesis of Mitochondria(Kroon, A. M. and Saccone, C., eds.), pp. 405-421, Academic Press, New York

70 Ebner, E., Mason, T. L. and Schatz, G. (1973) J. Biol. Chem. 248, 5369-5378

71 Ebner, E. and Schatz, G. (1973) J. Biol. Chem. 248, 5379-5384

72 Schwab, A. J., Sebald, W. and Weiss, H. (1972) Eur. J. Biochem. 30, 511-516

73 Nader, G. J., Stuchell, R. N. and Beattie, D. S. (1973) Eur. J. Biochem. 36, 519-527

74 Folch, J. and Lees, M. (1951) J. Biol. Chem. 191, 807-817

75 Sierra, M. F. and Tzagoloff, A. (1973) Proc. Natl. Acad. Sci. U.S. 70, 3155-3159

76 Capaldi, A. R. and Vanderkooi, G. (1972) Proc. Natl. Acad. Sci. U.S. 69, 930-932

77 Tzagoloff, A. and Akai, A. (1972) J. Biol. Chem. 247, 6517-6523

78 Tzagoloff, A., Akai, A. and Needleman, R. B. (1975) J. Biol. Chem. 250, 8228-8235

79 Tzagoloff, A., Akai, A. and Foury, F. (1976) FEBS Lett. 65, 391-395

80 Beechey, R. B., Roberton, A. M., Holloway, T. and Knight, I. G. (1967) Biochemistry 6, 3867-3879

81 Bulos, B. and Racker, E. (1968) J. Biol. Chem. 243, 3891-3900

82 Cattell, K. J., Lindop, C. R., Knight, J. G. and Beechey, R. B. (1971) Biochem. J. 125, 169-177

83 Catterall, W. A. and Pedersen, P. L. (1971) J. Biol. Chem. 246, 4987-4994

84 Knowles, A. F. and Penefsky, H. S. (1972) J. Biol. Chem. 247, 6624-6630

85 Brooks, J. C. and Senior, A. E. (1972) Biochemistry 11, 4675-4678

86 Ephrussi, B., DeMargerie-Hottinger, H. and Roman, H. (1954) Proc. Natl. Acad. Sci. U.S. 41, 1065

87 Linnane, A. W., Haslam, I. M., Lukins, H. B. and Nagley, F. (1972) Annu. Rev. Microbiol. 26, 163-198

88 Borst, P. (1972) Annu. Rev. Biochem. 41, 336-376

89 Faye, G., Fukuhara, H., Grandchamps, C., Lazowska, J., Michel, F., Casey, J., Getz, G. S., Locker, J., Rabinowitz, M., Bolotin-Fukuhara, M., Coen, D., Deutsch, J., Dujon, B., Netter, P. and Slonimski, P. P. (1973) Biochimie 55, 779-792 
90 Kovać, L., Groot, G. S. P. and Racker, E. (1972) Biochim. Biophys. Acta 256, 55-65

91 Tzagoloff, A. (1975) in Electron Transfer Chains and Oxidative Phosphorylation (Quagliariello, E., Papa, S., Palmieri, F., Slater, E. C. and Siliprandi, N. eds.), pp. 185-192, North Holland Publishing Co., Amsterdam

92 Slonimski, P. P. and Tzagoloff, A. (1976) Eur. J. Biochem. 61, 27-41

93 Tzagoloff, A., Akai, A. and Needleman, R. B. (1975) Proc. Natl. Acad. Sci. U.S. 72, 2054-2057

94 Tzagoloff, A., Akai, A., Needleman, R. B. and Zulch, G. (1975) J. Biol. Chem. 250, 8236-8242

95 Parker, J. H., Trimble, Jr., I. R. and Mattoun, J. R. (1968) Biochem. Biophys. Res. Commun. $33,590-595$

96 Stuart, K. D. (1970) Biochem. Biophys. Res. Commun. 39, 1045-1051

97 Avner, P. R. and Griffiths, D. E. (1970) FEBS Lett. 10, 202-207

98 Wakabayashi, K. and Gunge, N. (1970) FEBS Lett. 6, 302-304

99 Wakabayashi, K. (1972) J. Antibiot. 25, 475-476

100 Avner, P. R. and Griffiths, D. E. (1973) Eur. J. Biochem. 32, 301-311

101 Avner, P. R. and Griffiths, D. E. (1973) Eur. J. Biochem. 32, 312-321

102 Avner, P. R., Coen, D., Dujon, B. and Slonimski, P. P. (1973) Mol. Gen. Genet. 125, 9-52

103 Shannon, C., Enns, R., Wheelis, L., Burchiel, K. and Criddle, R. S. (1973) J. Biol. Chem. 248, 3004-3011

104 Griffiths, D. E. and Haughton, R. L. (1974) Eur. J. Biochem. 46, 157-167

105 Griffiths, D. E., Haughton, R. L., Lancashire, W. E. and Meadows, P. A. (1975) Eur. J. Biochem. $51,393-402$

106 Lancashire, W. E. and Griffiths, D. E. (1975) Eur. J. Biochem. 51, 403-413

107 Lancashire, W. E. and Griffiths, D. E. (1975) Eur. J. Biochem. 51, 377-392

108 Griffiths, D. E., Lancashire, W. E. and Zanders, E. D. (1975) FEBS Lett. 53, 126-130

109 Goffeau, A., Colson, A. M., Landry, Y. and Foury, F. (1972) Biochem. Biophys. Res. Commun. $48,1448-1454$

110 Ebner, E., Mennucci, L. and Schatz, G. (1973) J. Biol. Chem. 248, 5360-5368

111 Werner, S. (1974) Eur. J. Biochem. 43, 39-48

112 Saccone, C. and Kroon, A. M. (1976) International Conference on the Genetic Function of Mitonchondrial DNA, North Holland Publishing Co., Amsterdam 